\title{
Resiliency in Adolescents Who Live in Disaster Area: Phenomenology Study
}

\author{
Ayu Widiawati \\ Universitas Muhammadiyah Surakarta \\ Ayuwidia201@gmail.com
}

\author{
Wiwien Dinar Pratisti \\ Universitas Muhammadiyah Surakarta \\ wdp206@ums.ac.id
}

\begin{abstract}
Indonesia is an archipelago country and located in the Pasific Ring Of Fire which is at risk of experiencing various kinds of natural disaster, such as floods, landslides and mountains erupted. Natural disaster certainly bring harm and suffering to the victims, especially in adolescent and not all of the people could survive from it. Resiliency was the term to describe the ability of individu to survive from traumatic event. The purpose of this study was to acquire and describe resiliences in adolescents who live in disaster areas, using qualitative methods and phenomenology study. Six informans were participated in this study. They were 2 adolescents from Kampung Sewu, 2 adolescents from Gunung Kidul, and 2 adolescents who live in Sleman. Kampung Sewu was the area which at risk for floods, Gunung Kidul was the area which at risk for landslides, and Sleman was the area that risk of mountains eruption. We used purposive sampling to determine the informans and content analysis to analyzed the data. The results showed that resilieces in adolescents who was living in disaster areas was indicate by the ability to adapt in various situations, keep doing school task at the times of disaster, and maintain healthy life. There was a different form of resiliences in the three types of disaster, in the floods area of the adolenscents knew what they supposed to do when got a warning of danger. But in areas of landslides and mountains eruptions, the adolenscent prefered to save their lives although they did not know what they supposed to do specificcaly. Factors that affected resiliency was individual characteristic, support of the family, and the environment, the goverment and types of disasters.
\end{abstract}

Keyword: disaster areas, adolescence, resiliency, flood, landslides, maountain eruption

\section{INTRODUCTION}

Indonesia is an archipelago country and is located in the Pacific Ring of Fire which Indonesia is a region with many tectonic activities. Indonesia must also continue to face the risks of natural disasters that include tsunamis, tectonic and volcanic earthquakes, floods. Disasters can occur naturally and artificially. Natural disasters occurs due to natural factors, while artificial disasters occurs due to human activities that mine rocks can cause excessive landslide. Ordinary people littering and exploiting crops like illegal logging can cause flooding.

Not only the volcanic eruption's disaster that is difficult to predict, the eruption of Mount Merapi in 2010 leaving a deep traumas for the victims who are not only parents but teenagers. They have been displaced for over
2 years, many of whom have been killed by devastating eruptions. Communities must adapt when they have to live in evacuations with minimal places, even food that must be shared with other refugees, toilets and for children should go to schools in refugee camps far from worthy words.

This can lead to various things including deaths, destruction of local infrastructure, the crippling economic activity and can also cause traumatic to the victim. Not only parents, adults, children and even teenagers can also be victims. Natural disasters experienced by someone received as a stimulus that provides experience and can affect the readiness of the individual itself, especially for adolescents who are still in the stage of recognizing identity and less able to control emotions. Based on the results of Blanchard and Bhoem's research [2] that the availability of disaster information provides them the readiness and confidence to be able to control the information. This readiness behavior is also supported by the individual's ability to bounce back from the trauma event that has taken place, this ability calledresilience.

\section{METHOD}

The subject of this research was adolescents who live in disaster prone areas of 6 people. Subject selection was done by using purposive sampling technique, based on criterion determined by researcher that was adolescent, age 14 until 17 years and live in disaster prone area. Two subjects live in Kampung Sewu, Solo (Surakarta), two live in Sleman, Jogjakarta and two live in Gunung Kidul, Jogjakarta. Identification of the informan showed in Table 1.

Methods of data collection using semi-structured interviews. The questions based on the aspects of resiliency e.g. emotion regulation, control of impuls (impuls control), optimism, causa-effect analysis, empathy, self efficacy and positive achievement. We used three stages for analysis data based on Patilima [3], namely data reduction, data explanation and conclusion. Data reduction is a stage of selection, focus, make an abstract from data and transform data. Data explanation is a stage of explanation the data in a systematic ways. Conclusion is stage of giving the meaning of data based on themes, configuration, causal-effects relation, and proportions. 
Table 1. Identity of Informant

\begin{tabular}{llclll}
\hline \hline Subject & Age & Education & Status & Address & Gender \\
\hline AK & 14 years & SMP & Student & Gunung Kidul & female \\
\hline DR & 17 years & SMA & Student & Gunung Kidul & male \\
\hline AR & 16 years & SMA & Student & Sleman & female \\
\hline AT & 16 years & SMK & Student & Sleman & male \\
\hline MA & 17 years & SMA & Student & Solo & female \\
\hline BT & 15 years & SMP & Student & Solo & male \\
\hline \hline
\end{tabular}

\section{RESULT}

The purpose of this study was to determine the form of resilience in adolescents who live in disasters areas prone and factors that probably affect resilience in adolescents who live in disaster prone areas. In this study, researchers collected data from 6 informant came from 3 areas that have different types of disasters, namely floods in Kampung Sewu, Solo (Surakarta), landslides in Gunung Kidul (Yogyakarta), and volcanoes erupted in Sleman (Yogyakarta). Kampung Sewu is small area in Jebres, Solo which was lays in riverbanks of Bengawan Solo. Bengawan Solo is the longest river in Java. If it was rainy, the riverbanks area will become floods. Gunung Kidul is one district of Yogyakarta which was known as calcite mine. If it was rainy, the landslides will be happen. Sleman is one district of Yogyakarta where Mountain Merapi lays on. In last five years, mountain Merapi get eruption often recently.

From the answer of the subject, we knew about emotion regulation of the informan. All of the informans said that they become worried about loose things the ever had, worried about death, and become calmly if they knew what should they do. So, they tried to decreased their worried by learn the proper ways to adapt the situation. They also need support from their parents and the government to adapt with the situation. When the disaster came, they want to move to safety placed because they knew that they live in danger area. But they never went to anywhere because parents and government support them. And they become more optimistic to face the future. Another result showed that they realized that every problem had the solution. It can solve by asking parent to help or trying to solve the problems by theirselves. The informan also showed empathy to others by helping people in the same areas or support them carefully. Although they live in disaster area, adolescents keep their motivation to continue their study and their live.

In general, the results showed that adolescents who live in flood-prone areas knew what they should do when the flood came and understand the first thing done when the flood came. It was shown by clearing every things up and put it in a higher place. This is in accordance with the opinion of Setyowati [5] which states that resilience is an individual's ability to overcome challenges/ difficulties in his life and good health and energy so that individuals can continue to live prosperously.
The form of resilience in adolescents who live in landslides areas prone, the two subjects were worried because of the vibration and the sound of land collapse so hard and immediately rushed to escape, but after the disaster happened subject stayed in the area. In addition, according to local residents, the cause of landslide is man-made, although the subject remains in good contact with the perpetrator, the subject also forgive and feel sorry for the victim who was the perpetrator's family. After landslide events make the subject more alert and cautious when the rainy season arrives. This was in accordance with Setiawan and Pratitis [4] which states that resiliency is an individual's success in adjusting to the pressure that occurs, it describes the capacity of self to build positive results in events that suppress individuals. The form of resilience in adolescents who live in volcanic eruption disaster prone areas, when hearing the rumble the two subjects run immediately and did not bring these things. It could make the subject became apart from the parents. The subject takes \pm 2 years to forget the fear and need to take a counseling to reduce the fear experienced. This was in line with Flannery's description about trauma as fear when individuals were faced with sudden, unexpected, potentially life-threatening events that can not be controlled and individuals can not respond effectively as they should [1]

Mountain disaster erupts make the subject feel sad because many brothers are not survived, the subject was able to overcome the problems that arise when they stayed in evacuation. Subjects were able to perform activities as usual in their homes after 2 years in refugee and re-energized in achieving the ideals as well as experienced by the subject who lives in the area of flood. While in the refuge both subjects feel more familiar and closer each other as victims and help each other, because the flood comes every year both subjects can solve the problems that arise. The coming floods do not dampen the spirit of the subject in reaching the ideals, this was in accordance with the aspects that exist in the resilience according to Reivich and Shatte [6] the first cause-effect analysis. Cause-effect analysis is a person's ability to accurately identify the cause of the problem. Empathy is the ability to read other people's behavior by understanding the psychological and emotional signs and building better relationships, the three reaching positive ones. Achieving the positive is the ability to overcome severe problems or recover from trauma but also enrich life. 
Factors affecting the resilience of adolescents who lives in disaster-prone areas are individual characteristics here can be seen from individual readiness in the face of disaster. Family influence was the support provided by the family that can be accompanying the subject when the subject requires it to be seen on the subject living in the area prone to landslides. The environment around which mutual belonging and mutual help when the subject needs help, institutional or can be seen from school or government support that provides support when the subject was scared when the disaster comes was seen in the subject living in flood-prone areas and erupted volcanoes. This is consistent with factors affecting adolescent resilience according to Patilima [3]. The individual's nature that enhances resilience was an individual with good relationships, humor, self-control, optimism, flexibility, curiosity, confidence. The role of families in building child resilience was a protective factor that shapes the child's resources and promotes individual resilience. Education and schools can play a special role by providing emotional support in a variety of ways, including understanding the feelings of children who may be overwhelmed with anger, fear, guilt, and encouraging them to express themselves, as well as understanding their concentration problems.

In addition to the factors mentioned there are also other factors that affect the resilience of the type of disaster, because here we researched in three disaster areas. Research conducted in flood-prone areas indicates that the subject was able to adapt has become accustomed to the flood and has received a warning to prepare what should be packaged. Research conducted in landslide and volcanic eruptions indicates the subject takes time to relieve fear, which is consistent with Flannery's opinion that describes trauma as fear when individuals were faced with sudden, unexpected events, potentially life-threatening so that it can not be controlled and individuals can not respond effectively as it should [1]

\section{CONCLUSION}

The form of resilience encountered in adolescents who live in disaster prone areas was able to adapt in various situations which was the form of behavior from the aspect of impulse control. Staying on school tasks when affected by a disaster that was a form of behavior from the aspect of achieving a positive. Keep physical health, have a sense of kinship with fellow in vigitive camp which was the form of behavior from the aspect of empathy. Have ideals and strive to achieve that was the form of behavior from optimistic aspects and self efficacy. The different form of resilience of the three types of disasters that was in the area of the flood the subject knows what to do when the danger warning which was an accordance with a form of behavior from the aspect of causal analysis, but in areas of landslides and volcanoes erupted the subject was only concerned with the safety of the soul and became panic that was a form of behavior from the aspect of emotional regulation.

Based on the results of research factors affecting resilience in adolescents living in disaster prone areas that are individual characteristics, family influence, environment, institutional and types of disasters. Prominent factors in the flood-prone areas of environmental factors and individual characteristics, which stand out in landslide-prone areas of family support, and prominent in volcano-prone areas are institutions that include schools and government.

\section{REFERENCES}

[1] Hensley, B.J., EdB. An EMDR primer from practicum to practice. springer publishing company. New York 2009.

[2] Major, A.M."Gender differences in risk and communication behavior: Response to the New Madrid earthquake prediction" International Journal of Mass Emergency and Disasters, vol 17 1999.

[3] Patilima, H. Metode penelitian kualitatif. Bandung: Alfabeta 2005.

[4] Setiawan, A.N. T. \& Pratitis Religiusitas, dukungan sosial dan resiliensi korban lumpur lapindo sidoarjo. Persona, Jurnal Psikologi Indonesia, 4 (2) 2015.

[5] Setyowati, A. Hubungan antara kecerdasan emosional dengan resiliensi pada siswa penghuni rumah damai. Jurnal Psikologi Undip, 7 (1) 2010.

[6] Taufiq, R., Susanty, E., S, D. T., \& Nurlina, E. Gambaran resiliensi anak pasca benca banjir di desa dayeuhkolot, Kabupaten Bandung ,Jawa Barat.Wacana Jurnal Psikologi,6 (11), 252014. 